\title{
BIOETHANOL PRODUCTION FROM DRY ULVA LACTUCA ALGAE BY ALCOHOLIC FERMENTATION
}

\author{
DOINIT⿱A R. CIOROIU TÎRPAN, ${ }^{*}$ CLAUDIA I. KONCSAG, ${ }^{*}$ ALINA G. CIUFU, ${ }^{* *}$ \\ OANA C. PÂRVULESCU** and TĂNASE DOBRE*** \\ *Ovidius University of Constanta, 124, Mamaia Blvd., 900527 Constanta, Romania \\ ***olytechnic University of Bucharest, Chemical and Biochemical Engineering Department, \\ 1-3, Gheorghe Polizu Str., 011061 Bucharest, Romania \\ $\square$ Corresponding author: Alina G. Ciufu, alinag.ciufu@gmail.com
}

Received November 30, 2018

This study focuses on alcoholic Sacharomyces cerevisiae yeast fermentation of suspensions from Ulva lactuca sp. powder, after the enzymatic hydrolysis of polysaccharides with Aspergillus niger cellulase. Bioethanol production from algae is a complex process, depending mainly on the content of fermentable sugars in the raw material. The drying process is an important step in treating fresh algae harvested from the sea, in order to prevent algae gelling. In order to investigate the effect of process factors, a $2^{4}$ factorial experiment was designed. The effect of the following factors was studied: solid to liquid ratio $(S=1 / 12$ and $1 / 24)$, cellulase ratio $(U=8$ and $16 \mathrm{U} / \mathrm{g} \mathrm{d} . \mathrm{m}$.), alcoholic fermentation temperature $\left(t=25\right.$ and $\left.35^{\circ} \mathrm{C}\right)$ and mean particle diameter $(M=304$ and $1279 \mu \mathrm{m})$. The mathematical model predicting the yield of volatile compounds (V) and ethanol (E) in $\mathrm{g} / \mathrm{g} \mathrm{d.m.} \mathrm{was} \mathrm{obtained} \mathrm{by} \mathrm{regression.}$

Keywords: Ulva lactuca, cellulase, enzymatic hydrolysis, alcoholic fermentation

\section{INTRODUCTION}

Following the $21^{\text {st }}$ Conference of the Parties to the United Nations Framework Convention on Climate Change (UNFCCC) in Paris, the experts warned that if state authorities do not take the necessary measures to reduce greenhouse gas (GHG) emissions, the climate will heat up: (i) the ice ridges at the poles will melt; (ii) the snow cover on mountain ranges will decrease; (iii) this will lead to an increase in the sea level and the coast line will change dramatically; (iv) heavy rains, storms and floods will affect inhabited areas and agricultural lands. ${ }^{1}$ One of the main strategies for reducing carbon dioxide emissions into the atmosphere would consist in the large-scale use of biofuels instead of fossil fuels. ${ }^{2}$ Biofuels are gaseous or liquid fuels made from materials containing sugar and starch (first generation of bioethanol), ${ }^{3}$ cellulosic wastes and agricultural residues (second generation of ethanol), ${ }^{4}$ and aquatic-derived resources (third generation of ethanol). ${ }^{5}$

Marine biofuels represent renewable fuels derived from algal biomass via different conversion processes. ${ }^{6}$ A method for bioethanol production from Ulva lactuca sp. powder in aqueous suspension was reported, consisting in enzymatic hydrolysis, followed by ethanolic fermentation. ${ }^{7,8}$

Ulva lactuca sp. is a type of green macroalgae in the division Chlorophyta found on the Romanian Black Sea coast, which contains important bioactive compounds, such as polysaccharides, proteins, fatty acids and vitamins. ${ }^{9,10}$ Seaweeds can complete a life cycle in a few days because they have a high rate of growth, compared to terrestrial plants, if necessary conditions are assured. ${ }^{11,12}$

\section{EXPERIMENTAL}

\section{Materials and procedure}

Fresh algae were collected from the seaside, between the area of Pescarie and Mamaia, Constanta, Black Sea shore, on May, 2017. Epiphytic plants and impurities were removed mechanically and then the algae were rinsed with seawater and quickly transported to the laboratory in plastic containers, where the fresh algae were washed again, but this time with distilled water, dried at $45{ }^{\circ} \mathrm{C}$ in hot air to constant weight and crushed. ${ }^{13}$ The drying process 
consumes a lot of energy, which will be reflected in the total cost of algae conversion into bioethanol. ${ }^{14}$ The advantage will be the availability of raw material throughout the year and not just in the summer season, when it can be used fresh.

The dry matter (d.m.) in the following study and in the developed models refers to the algae dried to constant weight at $45{ }^{\circ} \mathrm{C}$. In fact, drying is not complete in this case, and it depends on the applied drying conditions. In order to compare the performance of the applied process for algae, a reference method was adopted to define "complete dryness": the humidity measurements were performed with an Ohaus Thermobalance, after drying for 7 minutes at $200{ }^{\circ} \mathrm{C}, 1$ minute at $150{ }^{\circ} \mathrm{C}$ and 12 minutes at $105{ }^{\circ} \mathrm{C}$. In this experiment, the algae dried at $45^{\circ} \mathrm{C}$ to constant weight still contained $28.33 \%$ humidity, compared to the one dried by the reference method.

Reducing particle size is a significant way to increase the contact surface between the enzymes and the raw material. Ulva lactuca powder was passed through certified granulometric sieves, initially through a mesh size of $3.15 \mathrm{~mm}$, then through a sieve with a mesh size of $630 \mu \mathrm{m}$. Thus, three fractions of powder were obtained: one with a size higher than 3.15 $\mathrm{mm}$, one with a size between $630 \mu \mathrm{m}$ and $3.15 \mathrm{~mm}$, and one with particles smaller than $630 \mu \mathrm{m}$. Further, the two fractions with smaller particle size were retained in order to perform the experiment. A sample of dry Ulva lactuca sp. was observed by an IOR Optical Transmission Microscope (60x magnification) and presented in Figure 1. The particle size was measured and the mean particle diameter for each fraction was calculated: (i) for the fraction with $\mathrm{d}<$ $630 \mu \mathrm{m}$, the mean diameter was $304 \mu \mathrm{m}$, with a standard deviation of $170 \mu \mathrm{m}$; (ii) for the fraction 630 $\mu \mathrm{m}<\mathrm{d}<3.15 \mathrm{~mm}$, the mean diameter was $1279 \mu \mathrm{m}$, with a standard deviation of $489 \mu \mathrm{m}$.

\section{Enzymatic activity of cellulase}

According to the literature, the carbohydrates content of Ulva lactuca sp. ranges from 45.0 to $61.5 \%$ on dry matter weight. ${ }^{10}$ The Ulva lactuca used in this study contained $55.0 \%$ carbohydrates, measured by the spectrophotometric method.

A commercial cellulolytic enzyme, cellulase, produced by Sigma Aldrich, representing off-white powder, $0.8 \mathrm{U} / \mathrm{mg}$, obtained from Aspergillus niger, was used to convert the carbohydrates from algae into fermentable sugars. ${ }^{15,16}$

Prior to the experiment, the enzymatic activity of cellulase was checked on pure microcrystalline cellulose from Sygma Aldrich, in an integrated process of hydrolysis-ethanolic fermentation, by comparing the yield of alcohol obtained in the process with the theoretical yield given by the stoichiometry of cellulose saccharification, followed by sugar fermentation. ${ }^{17}$ It is assumed that all the glucose was transformed into alcohol, given that optimum conditions were ensured $(\mathrm{pH}$, water quantity, temperature, enzyme concentration).

The procedure was as follows: $8 \mathrm{~g}$ of cellulose in $450 \mathrm{~mL}$ and $1 \mathrm{~g}$ cellulase (corresponding to $100 \mathrm{U} / \mathrm{g}$ cellulose), to ensure complete hydrolysis, were incubated for $24 \mathrm{~h}$ at $40{ }^{\circ} \mathrm{C}$. Then, the hydrolysate with a $\mathrm{pH}$ of 5-5.5 was fermented with Sacharomyces cerevisae $(1 \mathrm{~g})$, at $30{ }^{\circ} \mathrm{C}$, under slow agitation, in the dark for $48 \mathrm{~h}$. The quantity of $\mathrm{CO}_{2}$ produced during alcoholic fermentation was measured with a laboratory gasometer and reported to the ethanol formed. Following the stoichiometry of both reactions in series, the theoretical yield of ethanol should be $0.479 \mathrm{~g}$ ethanol/g cellulose, but the practical yield was 0.4073 $\mathrm{g}$ ethanol/g cellulose, so an enzymatic activity of $85 \%$ was calculated.

\section{Enzymatic hydrolysis of algae}

For enzymatic hydrolysis, $180 \mathrm{~g}$ of dry Ulva lactuca sp. was boiled in a quantity of distilled water (the solid to liquid ratio $\mathrm{S}=1 / 12$ or $\mathrm{S}=1 / 24$ ) for 20 minutes. After cooling to $40-45{ }^{\circ} \mathrm{C}$, cellulase was added in the desired ratio ( $8 \mathrm{U} / \mathrm{g}$ d.m. or $16 \mathrm{U} / \mathrm{g} \mathrm{d.m.).}$ The mixture was maintained at this temperature in an orbital shaker for 24 hours. Then, the insoluble plant material was separated and the hydrolysate was further processed by alcoholic fermentation.

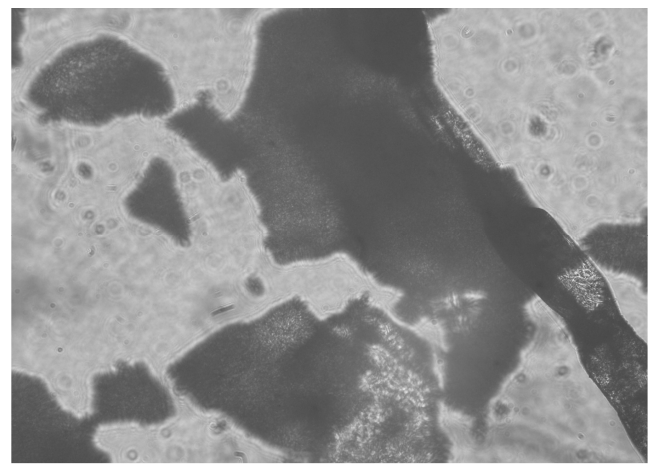

Figure 1: Microscopy image (60x magnification) of dry Ulva lactuca algae 


\section{Alcoholic fermentation}

The study of Lee and Lee, regarding ethanol fermentation, ${ }^{18}$ demonstrated that from 8 types of strains, Sacharomyces cerevisiae was found to produce the highest ethanol yield (up to $2.59 \mathrm{~g} / \mathrm{L}$ ). Therefore, for this experiment, commercial Sacharomyces cerevisiae yeast, provided by S.C. LESAFFRE Romania, S.R.L., was used.

In order to start the alcoholic fermentation, $1 \mathrm{~g}$ of Sacharomyces cerevisiae yeast was added to the hydrolysate. ${ }^{19,20}$ The fermentation was carried out at 25 or $35^{\circ} \mathrm{C}$ for 24 hours under anaerobic conditions. The carbon dioxide production resulting from the fermentation was measured and reported in ethanol production. The concentration of volatile compounds from the fermentation medium was determined by distillation in an oenologic Glass-CHEM apparatus, Italy, model $\mathrm{OH}-$, using the Romanian standard method SR 184-2. ${ }^{10}$

\section{Experiment design}

It was assumed that the main factors influencing the process are the following: the suspension concentration, the amount of cellulose from Aspergillus niger related to the biomass amount, the fermentation temperature and the particle size in the suspension.

In order to investigate the effect of process factors, a $2^{4}$ factorial experiment was designed. The factors were as follows: the solid to liquid ratio $(S=1 / 12$ and $1 / 24)$, the cellulase ratio ( $U=8$ and $16 \mathrm{U} / \mathrm{g} \mathrm{d.m.),} \mathrm{the}$ alcoholic fermentation temperature $\left(t=25\right.$ and $\left.35{ }^{\circ} \mathrm{C}\right)$ and the particle size $(M=304$ and $1279 \mu \mathrm{m})$.

The experiment consisted in 16 duplicate determinations (32 samples). ${ }^{8}$

\section{RESULTS AND DISCUSSION}

The volatile and ethanol yields obtained in the experiment and expressed as g/g d.m. are shown in Table 1. In the last two columns in Table 1, the yields corrected for "complete dryness" of algae are presented. This allows comparing the performance (yields) of the process with that of other processing methods, for example, with a previous work performed on fresh algae. ${ }^{10}$

The maximum alcohol yield was $0.0211 \mathrm{~g} / \mathrm{g}$ d.m., obtained under the following conditions: solid:liquid ratio of $1 \mathrm{~g} \mathrm{~d} . \mathrm{m} . / 24 \mathrm{~g}$ water, cellulase ratio of $16 \mathrm{U} / \mathrm{g} \mathrm{d}$.m., process temperature of $35{ }^{\circ} \mathrm{C}$ and medium particle diameter of $304 \mu \mathrm{m}$. The yields in this experiment were comparable with previously reported results for fresh Ulva lactuca ${ }^{10}$ where the maximum ethanol yield was $0.0234 \mathrm{~g} / \mathrm{g} \mathrm{d}$.m., corresponding to a production of $0.34 \mathrm{~kg}$ ethanol $/ 100 \mathrm{~kg}$ fresh algae, and in the same range as the findings for other macrophytes, from $0.23 \mathrm{~kg}$ ethanol $/ 100 \mathrm{~kg}$ fresh weight
Kappaphycus alvarezii, ${ }^{21}$ to $0.38 \mathrm{~kg}$ ethanol $/ 100$ $\mathrm{kg}$ fresh Gracilaria verrucosa. ${ }^{22}$

The mathematical model, predicting the volatile compounds yield (V) (Eq. 1) and the ethanol yield (E) (Eq. 2) in g/g d.m., was obtained by regression, using Microsoft Excel:

$V=-0.09486-0.000038 M+0.010703 t-0.72892$

$S+0.006025 U$

$E=-0.00679-0.000001 M+0.00048 t-0.00331$

$S+0.00035 U$

Model fitting was performed and the significance of the coefficients was demonstrated by ANOVA.

All coefficients from Equation (1) are statistically significant $(\mathrm{p}<0.05)$, as can be seen in Table 2, following the statistical processing of data. From Equation (1), it can be seen that the volatile yield decreases with increasing particle size and solid/liquid ratio, and increases with temperature and applied cellulase ratio. However, some of the factors (particle size and cellulase ratio) influence the process to a lesser extent, at least in the experimental range, because the corresponding coefficients are much lower than those for temperature and solid:liquid ratio. From the residue analysis (Table 3), there are small differences between the values predicted with the model (Eq. 1) and those obtained experimentally, so the model can be considered as reliable.

The statistical parameters of Equation (2) are good (see Table 4), except for the coefficients that resulted for particle size $\left(\mathrm{M}\right.$, variable $\left.\mathrm{x}_{1}\right)$ and solid:liquid ratio $\left(\mathrm{S}\right.$, variable $\left.\mathrm{x}_{3}\right)$. As a result, the model was reformulated ignoring the terms $\mathrm{x}_{1}$ and $\mathrm{x}_{3}$, and the following relation (Eq. 3) resulted:

$E=-0.00679+0.00048 t+0.00035 U$

From the analysis of residues (Table 5), there are small differences between the values predicted by the model (Eq. 3) and those obtained experimentally, so the model is reliable.

The model (Eq. 3) shows that the only factors influencing significantly the ethanol yield are the fermentation temperature and the cellulase ratio added during the saccharification step. It can be concluded that crushing biomass below the average size of $1274 \mu \mathrm{m}$ does not lead to improved ethanol yield. Meanwhile, the dilution of the suspension biomass from the solid mass ratio $1 / 12$ to $1 / 24$ does not bring any significant increase in ethanol yield either. 
DOINIȚA R. CIOROIU TÎRPAN et al.

Table 1

Yields of volatile compounds and ethanol obtained from the alcoholic fermentation of dry Ulva lactuca sp.

\begin{tabular}{|c|c|c|c|c|c|c|c|c|}
\hline $\begin{array}{l}\text { Average particle } \\
\text { diameter } d, \mu \mathrm{m}\end{array}$ & $\begin{array}{l}\text { No. } \\
\text { sample }\end{array}$ & $\begin{array}{l}\text { Temp., } \\
{ }^{\circ} \mathrm{C}\end{array}$ & $\mathrm{S} / \mathrm{L}$ ratio & $\begin{array}{l}\mathrm{U} / \mathrm{mg} \\
\text { d.m. }\end{array}$ & $\begin{array}{c}\text { Yield of } \\
\text { volatiles V, } \\
\text { g/g d.m. }\end{array}$ & $\begin{array}{l}\text { Yield of } \\
\text { ethanol E, } \\
\text { g/g d.m. }\end{array}$ & $\begin{array}{l}\text { Corrected yield of } \\
\text { volatiles V, } \\
\text { g/g d.m. }\end{array}$ & $\begin{array}{l}\text { Corrected yield } \\
\text { of ethanol E, } \\
\text { g/g d.m. }\end{array}$ \\
\hline \multirow{8}{*}{304} & 1 & 25 & $1 / 12$ & 16 & 0.1858 & 0.0109 & 0.2592 & 0.0152 \\
\hline & 2 & 25 & $1 / 12$ & 8 & 0.1475 & 0.0066 & 0.2058 & 0.0092 \\
\hline & 3 & 25 & $1 / 24$ & 16 & 0.2158 & 0.0120 & 0.3011 & 0.0167 \\
\hline & 4 & 25 & $1 / 24$ & 8 & 0.1775 & 0.0077 & 0.2477 & 0.0107 \\
\hline & 5 & 35 & $1 / 12$ & 16 & 0.3335 & 0.0147 & 0.4653 & 0.0205 \\
\hline & 6 & 35 & $1 / 12$ & 8 & 0.2518 & 0.0124 & 0.3513 & 0.0173 \\
\hline & 7 & 35 & $1 / 24$ & 16 & 0.3520 & 0.0151 & 0.4911 & 0.0211 \\
\hline & 8 & 35 & $1 / 24$ & 8 & 0.2688 & 0.0136 & 0.3751 & 0.0190 \\
\hline \multirow{8}{*}{1274} & 9 & 25 & $1 / 12$ & 16 & 0.1606 & 0.0101 & 0.2241 & 0.0141 \\
\hline & 10 & 25 & $1 / 12$ & 8 & 0.1270 & 0.0062 & 0.1772 & 0.0087 \\
\hline & 11 & 25 & $1 / 24$ & 16 & 0.1775 & 0.0105 & 0.2477 & 0.0147 \\
\hline & 12 & 25 & $1 / 24$ & 8 & 0.1654 & 0.0070 & 0.2308 & 0.0098 \\
\hline & 13 & 35 & $1 / 12$ & 16 & 0.2458 & 0.0144 & 0.3430 & 0.0201 \\
\hline & 14 & 35 & $1 / 12$ & 8 & 0.2122 & 0.0121 & 0.2961 & 0.0169 \\
\hline & 15 & 35 & $1 / 24$ & 16 & 0.3070 & 0.0140 & 0.4284 & 0.0195 \\
\hline & 16 & 35 & $1 / 24$ & 8 & 0.2422 & 0.0129 & 0.3379 & 0.0180 \\
\hline
\end{tabular}

Table 2

ANOVA analysis for the coefficients of Equation (1)

\begin{tabular}{|c|c|c|c|c|c|}
\hline & Coefficients & Standard error & P-value & Lower 95\% & Upper $95 \%$ \\
\hline Intercept & -0.09486 & 0.03304 & 0.0152 & -0.1676 & -0.0221 \\
\hline Variable $\mathrm{x}_{1}(\mathrm{M})$ & -0.00004 & 0.00001 & 0.0014 & -0.0001 & 0.0000 \\
\hline Variable $x_{2}(t)$ & 0.01070 & 0.00087 & $1 \mathrm{E}-07$ & 0.0088 & 0.0126 \\
\hline Variable $x_{3}(S)$ & -0.72892 & 0.20973 & 0.0052 & -1.1905 & -0.2673 \\
\hline Variable $\mathrm{x}_{4}(\mathrm{U})$ & 0.00603 & 0.00109 & 0.0002 & 0.0036 & 0.0084 \\
\hline
\end{tabular}

Multiple $\mathrm{R}=0.9750, \mathrm{R}$ square $=0.9506$, Adjusted $\mathrm{R}$ square $=0.9327$, Standard error $=0.0174$ 
Cellulase

Table 3

Comparison of volatile compounds yields predicted with Eq.(1) and the experimental values

\begin{tabular}{cccc}
\hline \multicolumn{4}{c}{ Residual output } \\
\hline Observation & Predicted y & Experimental y & Residuals \\
\hline 1 & 0.1970 & 0.1858 & -0.0112 \\
2 & 0.1488 & 0.1475 & -0.0013 \\
3 & 0.2273 & 0.2158 & -0.0115 \\
4 & 0.1791 & 0.1775 & -0.0016 \\
5 & 0.3040 & 0.3335 & 0.0294 \\
6 & 0.2558 & 0.2518 & -0.0040 \\
7 & 0.3343 & 0.3520 & 0.0176 \\
8 & 0.2861 & 0.2688 & -0.0173 \\
9 & 0.1601 & 0.1606 & 0.0004 \\
10 & 0.1119 & 0.1270 & 0.0150 \\
11 & 0.1904 & 0.1775 & -0.0129 \\
12 & 0.1422 & 0.1654 & 0.0231 \\
13 & 0.2672 & 0.2458 & -0.0214 \\
14 & 0.2190 & 0.2122 & -0.0068 \\
15 & 0.2974 & 0.3070 & 0.0095 \\
16 & 0.2492 & 0.2422 & -0.0070 \\
\hline
\end{tabular}

Table 4

ANOVA analysis for the coefficients of Equation (2)

\begin{tabular}{lccccc}
\hline & Coefficients & Standard error & P-value & Lower 95\% & Upper 95\% \\
\hline Intercept & -0.00679 & 0.00148 & 0.0008 & -0.01006 & -0.00353 \\
Variable $\mathrm{x}_{1}(\mathrm{M})$ & 0.000001 & 0.000001 & 0.1179 & 0.000002 & $2.03 \mathrm{E}-07$ \\
Variable $\mathrm{x}_{2}(\mathrm{t})$ & 0.00048 & 0.00004 & $8 \mathrm{E}-08$ & 0.00040 & 0.00057 \\
Variable $_{3}(\mathrm{~S})$ & -0.00331 & 0.00941 & 0.7315 & -0.02403 & 0.017401 \\
Variable $\mathrm{x}_{4}(\mathrm{U})$ & 0.00035 & 0.00005 & $2 \mathrm{E}-05$ & 0.00025 & 0.000462 \\
\hline
\end{tabular}

Multiple $\mathrm{R}=0.97470, \mathrm{R}$ square $=0.95004$, Adjusted R square $=0.93188$, Standard error $=0.00078$, Observation $=16$

Table 5

Comparison of ethanol yields predicted by Equation (3) and the experimental values

\begin{tabular}{cccc}
\hline \multicolumn{4}{c}{ Residual output } \\
\hline Observation & Predicted y & Experimental y & Residuals \\
\hline 1 & 0.0108 & 0.0109 & 0.0001 \\
2 & 0.0080 & 0.0066 & -0.0014 \\
3 & 0.0108 & 0.0115 & 0.0007 \\
4 & 0.0080 & 0.0077 & -0.0003 \\
5 & 0.0156 & 0.0147 & -0.0009 \\
6 & 0.0128 & 0.0124 & -0.0004 \\
7 & 0.0156 & 0.0151 & -0.0005 \\
8 & 0.0128 & 0.0136 & 0.0008 \\
9 & 0.0108 & 0.0101 & -0.0007 \\
10 & 0.0080 & 0.0062 & -0.0018 \\
11 & 0.0108 & 0.0105 & -0.0003 \\
12 & 0.0080 & 0.0070 & -0.0010 \\
13 & 0.0156 & 0.0144 & -0.0012 \\
14 & 0.0128 & 0.0121 & -0.0007 \\
15 & 0.0156 & 0.014 & -0.0016 \\
16 & 0.0128 & 0.0129 & 0.0001 \\
\hline
\end{tabular}


DOINIȚA R. CIOROIU TÎRPAN et al.
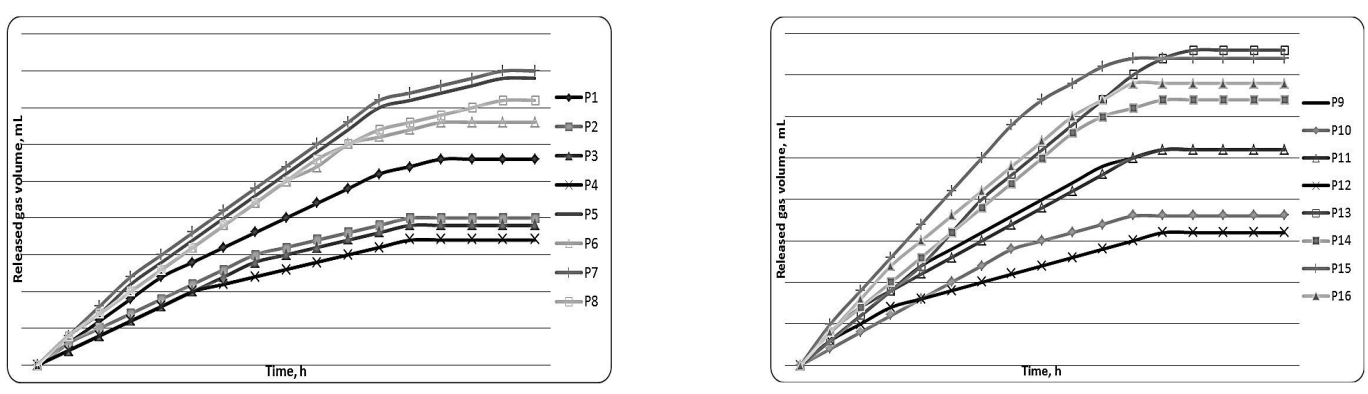

Figure 2: Fermentation rate for Ulva lactuca sp. with Figure 3: Fermentation rate for Ulva lactuca sp. with particle particle size below $630 \mu \mathrm{m}$ (samples 1-8 in Table 1) size of $630 \mu \mathrm{m}-3.15 \mathrm{~mm}$ (samples 9-16 in Table 1)

Figures 2 and 3, correlated with Table 1, show indirectly, through the dynamics of the gas volume, the fermentation rates for the Ulva lactuca sp. according to the operating parameters mentioned before. The kinetic curves in Figures 2 and 3 indicate that the alcoholic fermentation is complete after 7 hours.

\section{CONCLUSION}

Alcoholic fermentation of Ulva lactuca sp. Powder, in the presence of Sacharomyces cerevisiae, were studied. The effect of process factors (fermentation temperature $\left(25\right.$ and $35^{\circ} \mathrm{C}$ ), solid:liquid ratio $(1 \mathrm{~g}$ d.m. $/ 12 \mathrm{~g}$ water and $1 \mathrm{~g}$ d.m./24 g water), cellulase ratio (8 and $16 \mathrm{U} / \mathrm{g}$ d.m. in fresh algae) and different particle sizes of dry algae (304 and $1271 \mu \mathrm{m})$ ) was determined on the fermentation yield in volatile substances and ethanol. The optimal parameters of the process were found to be the following: solid: liquid ratio of $1 \mathrm{~g}$ d.m. $/ 24 \mathrm{~g}$ water, cellulase ratio of $16 \mathrm{U} / \mathrm{g}$ d.m., process temperature of $35{ }^{\circ} \mathrm{C}$ and medium particle diameter of $304 \mu \mathrm{m}$, when the alcohol yield was $0.0211 \mathrm{~g}$ alcohol $/ \mathrm{g}$ d.m., comparable to other data in the literature.

Mathematical models were proposed for correlating the product yields with the process factors. First-order polynomial equations resulted by regression of the experimental data. These models were statistically validated by good parameters of regression and statistical ANOVA analysis.

\section{REFERENCES}

1 J. C. M. Pires, Renew. Sust. Energ. Rev., 79, 867 (2017), https://doi.org/10.1016/j.rser.2017.05.197
2 O. K. Lee and E. Y. Lee, Biomass Bioenerg., 92, 70 (2016), https://doi.org/10.1016/j.biombioe.2016.03.038

L. Ge, P. Wang and H. Mou, Renew. Energ., 36, 84 (2011), https://doi.org/10.1016/j.renene.2010.06.001

4 L. Myat and G.-H. Ryu, Cellulose Chem. Technol., 50, 177 (2016), http://www.cellulosechemtechnol.ro/pdf/CCT2(2016)/ p.177-188.pdf

M. G. Borines, R. L. de Leon and J. L. Cuello, Bioresour. Technol., 138, $22 \quad$ (2013), https://doi.org/10.1016/j.biortech.2013.03.108

6 O. M. Adeniyi, U. Azimov and A. Burluka, Renew. Sust. Energ. Rev., 90, 316 (2018), doi: 10.1016/j.rser.2018.03.067

7 S. A. Jambo, R. Abdulla, S. H. M. Azhar, H. Marbawi, J. A. Gansau et al., Renew. Sust. Energ. Rev., $\quad \mathbf{6 5}, \quad 756 \quad$ (2016), https://doi.org/10.1016/j.rser.2016.07.064

8 D. R. Cioroiu Tîrpan, PhD Thesis, Polytechnic University of Bucharest, 2017.

9 S. Tian, X. Yin, Q. Zeng, L. Zhu and J. Chen, Int. J. Biol. Macromol., 79, $577 \quad$ (2015), https://doi.org/10.1016/j.ijbiomac.2015.05.031

10 D. R. Cioroiu, C. I. Koncsag, D. Gudovan and T. Dobre, Rev. Chim., 69, 1226 (2018).

11 S. R. Chia, H. C. Ong, K. W. Chew, P. L. Show, S.-M. Phang et al., Renew. Energ., 129, 838 (2018), https://doi.org/10.1016/j.renene.2017.04.001

12 P. V. Hoang Nhat, H. H. Ngo, W. S. Guo, S. W. Chang, D. D. Nguyen et al., Bioresour. Technol., 256, 491

https://doi.org/10.1016/j.biortech.2018.02.031

(2018),

${ }_{13}$ H. Yaich, H. Garna, S. Besbes, M. Paquot, C. Blecker et al., Food Chem., 128, 895 (2011), doi: 10.1016/j.foodchem.2011.03.114

14 Z. Shi, B. Zhao, S. Tang and X. Yang, J. Clean. Prod., 204, 906 (2018), https://doi.org/10.1016/j.jclepro.2018.08.351

15 C. V. T. Mendes, M. G. V. S. Carvalho and J. M. S. Rocha, Cellulose Chem. Technol., 51, 291 (2017), 
http://www.cellulosechemtechnol.ro/pdf/CCT3-

4(2017)/p.291-299.pdf

16 N. Trivedi, V. Gupta, C. R. K. Reddy and B. Jha,

Bioresour. Technol., 150, $106 \quad$ (2013), https://doi.org/10.1016/j.biortech.2013.09.103

17 D.-R. Cioroiu, C. I. Koncsag and T. Dobre, Bulletin of Romanian Chemical Engineering Society, 2, 33 (2015).

18 S.-M. Lee and J.-H. Lee, J. Ind. Eng. Chem. 18, 16 (2012), https://doi.org/10.1016/j.jiec.2011.11.097

19 J. T. Ellis, N. N. Hengge, R. C. Sims and C. D. Miller, Bioresour. Technol., 111, 491 (2012), https://doi.org/10.1016/j.biortech.2012.02.002

${ }^{20}$ M. H. Yoon, Y. W. Lee, C. H. Lee and Y. B. Seo, Bioresour. Technol., 126, $198 \quad$ (2012), https://doi.org/10.1016/j.biortech.2012.08.102

${ }_{21}$ Y. Khambhaty, K. Mody, M. R. Gandhi, S. Thampy, P. Maiti et al., Bioresour. Technol., 103, 180 (2012), https://doi.org/10.1016/j.biortech.2011.10.015

${ }^{22}$ S. Kumar, R. Gupta, G. Kumar, D. Sahoo and R. C. Kuhad, Bioresour. Technol., 135, 150 (2013), https://doi.org/10.1016/j.biortech.2012.10.120 